\title{
Comparison between the Quality Traits of Phosphate and Bicarbonate-Marinated Chicken Breast Fillets Cooked under Different Heat Treatments
}

\author{
Samer Mudalal, Massimiliano Petracci ${ }^{*}$, Silvia Tappi, Pietro Rocculi, Claudio Cavani
}

Department of Agricultural and Food Sciences, Alma Mater Studiorum-University of Bologna, Cesena, Italy. Email: ${ }^{*}$ m.petracci@unibo.it

Received July $25^{\text {th }}, 2013$; revised August $25^{\text {th }}, 2013$; accepted September $4^{\text {th }}, 2013$

Copyright (C) 2014 Samer Mudalal et al. This is an open access article distributed under the Creative Commons Attribution License, which permits unrestricted use, distribution, and reproduction in any medium, provided the original work is properly cited. In accordance of the Creative Commons Attribution License all Copyrights (C) 2014 are reserved for SCIRP and the owner of the intellectual property Samer Mudalal et al. All Copyright (C) 2014 are guarded by law and by SCIRP as a guardian.

\begin{abstract}
Because the use of phosphates has being recently diminished in meat industry due to the nutritional drawbacks of phosphates, some researchers started to evaluate sodium bicarbonate as phosphate replacer in meat products. The aim of this study was to evaluate the effect of different temperature combinations of dry air-cooking treatments (Air and Core temperatures: $160-76,160-80,200-76$ and $200^{\circ} \mathrm{C}-80^{\circ} \mathrm{C}$, respectively) on chemical composition, texture properties, water activity, freezable water and bound water, color, $\mathrm{pH}$, and water binding capacity of phosphate and bicarbonate-marinated chicken breast. A batch of $24 \mathrm{~h}$ post-mortem broiler breast meat of 80 fillets was divided into two groups of marination treatments $(0.3 \%$ sodium bicarbonate $n=40,0.3 \%$ sodium tripolyphosphate $n=40$ ) and was vacuum tumbled $(45 \mathrm{~min},-0.95 \mathrm{mbar}, 20 \mathrm{rpm})$. Different temperature-combinations cooking treatments significantly modified the chemical composition. Bicarbonate marinated fillets showed higher ability to retain water $(67.3 \%$ vs. $65.7 \%, P<0.05)$ during severe heat treatment and lower cook losses $(30.7 \%$ vs. $33.4 \%, P<0.05)$ when compared with phosphate-marinated fillets. The effect of changing the cooking temperatures on Texture Profile Analysis (hardness, cohesiveness, gumminess, springiness, and chewiness) was more tangible in phosphate marinated fillets than bicarbonate. Bicarbonate-marinated fillets showed significant differences in the percentage of bound water, latent heat, and water activity after cooking in comparison to phosphate-marinated fillets. The results of this study revealed that phosphate-marinated fillets interacted with heat treatments in different patterns in comparison with bicarbonate-marinated fillets.
\end{abstract}

\section{KEYWORDS}

Chicken Meat; Marination; Sodium Bicarbonate; Heat Treatment; Quality Traits

\section{Introduction}

Marination is one of the most common techniques that usually used to improve the flavor, tenderness, juiciness, stability and safety of meat from an aspect and enhance the yield from other aspect [1]. Several studies have implemented on marinated meat to evaluate processing conditions: time and type of marination, salt and polyphosphate concentration, cooking methods, and other processing parameters by employing several quality meas-

"Corresponding author. ures like marinade uptake, water retention, water binding capacity, cooking loss, texture and sensorial properties $[2,3]$. Particularly, pyrophosphate and tripolyphosphate are frequently used to increase the water binding capacity of meat. Sodium tripolyphosphate accounts for approximately $80 \%$ of the phosphates used in further-processed meat products. In this context, phosphates offer a wide range of functional properties to the processed meat products which rendered them as a preferable choice for meat producers. Phosphates can impart the functional properties to meat products in several synchronized ways: 
by shifting the $\mathrm{pH}$ far away from isoelectric point, increasing the ionic strength, and improving the solubilization of myosin and actin by sequestering $\mathrm{Mg}$ and $\mathrm{Ca}$ ions which are involved during the formation of actomyosins complex. Dissociation of actomyosins enhances the solubilization and the functional properties of proteins during processing [4]. Phosphates also have strong synergistic effect in presence of sodium chloride. Sodium chloride is used in combination of phosphate in marinades to improve the texture and yield of muscle meat products $[5,6]$.

Beside to the former unique characteristics, phosphates improve the oxidative stability, flavor and retard the microbial growth in meat products [7]. Recently, the use of phosphates has being diminished in meat industry due to some nutritional drawbacks of phosphates that come from their ability to interfere the absorption of some minerals in the gut by forming insoluble complexes with calcium and magnesium. Several countries have banned their use in raw meat production [8]. In response to these nutritional drawbacks, many studies started to evaluate some functional ingredients to replace the use of phosphate in meat products [9].

Carbonate and bicarbonate compounds are considered as a new promising agent as phosphate replacer. Some recent studies showed that bicarbonate compounds can be reduce by the drip loss and shear force, which improve the yield as well as phosphates. This effect could be explained because bicarbonates have higher buffering capacity and ionic strength than phosphates [9-11].

The impact of different heat treatments on the quality traits of marinated poultry meat had been evaluated. Air-steam treatment was one of the best methods for obtaining more tender chicken slices. It was found that the effect of cooking time on cooking loss was more than cooking temperature [12]. Low relative humidity-heat treatment showed higher quality traits for cooked turkey meat when compared to high steam treatment [13]. Cooking conditions (temperature and cooking time) have massive impact on physical characteristics of meat and eating quality.

Bicarbonate compounds have evaluated as a phosphate replacer under the same conditions of heat treatment $[10,11]$. Scarce in formations are available about the effect of bicarbonate in comparison to phosphates under different conditions of heat treatments. The aim of this study was to evaluate the effect of different heat treatments on breast fillets marinated with bicarbonate versus phosphates.

\section{Materials and Methods}

\subsection{Collection and Preparation of the Samples}

A batch of 80 skinless chicken breasts was obtained from commercial plant after $24 \mathrm{~h}$ postmortem from the same flock. The breast fillets were trimmed and adjusted to have the same raw weight $(141.0 \pm 0.9 \mathrm{~g})$. The samples were reorganized in two groups $(n=40)$ having the same average lightness values $\left(\mathrm{L}^{*}, 51.0 \pm 0.2\right.$ and $(50.9 \pm 0.2)$ for bicarbonate and phosphate marinating treatments, respectively.

The first group was marinated with sodium tripolyphosphate $(\mathrm{P})$ and the second group marinated with sodium bicarbonate (B) by vacuum tumbling (45 min, $-0.95 \mathrm{mbar}$, and $20 \mathrm{rpm}$ ) with target marination level $20 \%$ and $0.3 \%$ for each salt. Each type of marination treatment was divided into four groups $(\mathrm{n}=10)$ and subjected to different heat treatments by air oven (oven-core temperatures: 160 - 76 (A), 160 - 80 (C), 200 - 76 (D) and 200 $80^{\circ} \mathrm{C}(\mathrm{E})$.

\subsection{Analysis of Quality Traits}

The $\mathrm{pH}$ was determined using a modification of the iodoacetate method that was initially described by Jeacocke [14]. Approximately $2.5 \mathrm{~g}$ of meat sample before tumbling, after tumbling, and after cooking were used, minced by hand, homogenized in $25 \mathrm{~mL}$ of a $5 \mathrm{mM}$ iodoacetate solution with $150 \mathrm{mM}$ potassium chloride for $30 \mathrm{sec}$, and the $\mathrm{pH}$ of the homogenate was determined using a $\mathrm{pH}$ meter. Cooking loss was calculated from differences in the weights before and after cooking [15]. Marinade uptake was also determined by the difference in weights between marinated and green (fresh) meat, while purge loss was calculated by the difference in weight of the marinated meat before and after storage for $24 \mathrm{~h}$ under refrigerated conditions. Water activity $\left(\mathrm{a}_{\mathrm{w}}\right)$ was measured at a constant temperature $\left(25 \pm 1^{\circ} \mathrm{C}\right)$ by a water activity meter mod Aqualab (Decagon Devices Inc., Pullman, WA) that bases its measure on the chilledmirror dew point technique. For each marination treatment, $a_{w}$ was detected on 3 samples before tumbling, after tumbling, and after cooking. Proximate analysis (moisture, protein, lipid and ash contents) was performed according to the Association of Official Analytical Chemists procedure [16]. Moisture content of the cooked meat samples was determined by air-oven procedure, crude protein content was assessed by Kjeldahl method, lipid content was estimated by petroleum ether extraction using soxhlet method and total ash content was determined by the difference in weight after incineration at $525^{\circ} \mathrm{C}$ for $4 \mathrm{~h}$. The water holding capacity (WHC) of the raw breast cuts was measured by modified Van Laack method [17]. About $30 \mathrm{~g}$ of minced meat were homogenized with $90 \mathrm{ml}$ of $1 \%$ sodium chloride. Each $20 \mathrm{~g}$ of homogenized solution was centrifuged for $1 \mathrm{~min}$ at speed $22,000 \mathrm{rpm}$ and temperature $6^{\circ} \mathrm{C}-7^{\circ} \mathrm{C}$. The supernatant was removed to calculate the moisture uptake which was 
calculated as the difference in weight between fresh meat and the pellet after centrifugation.

The texture profile analysis was determined on cylindrical samples $(3 \mathrm{~cm}$ diameter, $2 \mathrm{~cm}$ height) were axially compressed (load cell: $50 \mathrm{~kg}$; crosshead test speed: 1 $\mathrm{mm} / \mathrm{s}$, distance: $5 \mathrm{~mm}$, force: $100 \mathrm{~g}$, time: $5 \mathrm{sec}$ ) to $50 \%$ of their initial height in a double compression cycle: hardness $(\mathrm{kg}$, maximum force required to compress the sample), cohesiveness (A2/A1, extent to which the sample could be deformed prior to rupture, where A1 represents the total energy required for the first compression and A2 the total energy required for the second compression), springiness (D2/D1, the ability of sample to recover its original shape after the deforming force is removed where D1 represents the initial compression distance and D2 the distance detected for the second compression), gumminess (hardness $\times$ cohesiveness, the force needed to disintegrate a semisolid sample to a steady state of swallowing), chewiness (springiness $x$ gumminess, the work needed to chew a solid sample to a steady state of swallowing). Shear force was determined on a meat strip (approximately $2 \times 4 \times 1 \mathrm{~cm}$ ) which was excised from each cooked sample parallel to the fiber direction. Strips were sheared perpendicular to fiber direction using a TA.HDi Heavy Duty texture analyzer (Stable Micro Systems Ltd., Godalming, Surrey, UK) equipped with Allo-Kramer shear cell using the procedure described by Sams et al. [18]. Shear values are reported as kilograms of shear force per gram of sample.

The amount of Freezable water (FW) was evaluated by a Pyris 6 DSC (Perkin Elmer Corp., Wellesley, MA) on 3 samples per group after tumbling and after cooking. The DSC was equipped with a low-temperature cooling unit Intacooler II (Perkin Elmer Corp.). Temperature calibration was performed with ion-exchanged distilled water (melting point $0.0^{\circ} \mathrm{C}$ ), indium (melting point $156.60^{\circ} \mathrm{C}$ ), and zinc (melting point $419.47^{\circ} \mathrm{C}$ ). Heat flow was calibrated using the heat of fusion of indium $(\Delta \mathrm{h}=28.71 \mathrm{~J} / \mathrm{g})$. For the calibration, the same heating rate used for sample measurements was applied, and a dry nitrogen gas flux of $20 \mathrm{~mL} / \mathrm{min}$ was used. Each sample (about $20 \mathrm{mg}$ ) was weighed in a $50-\mu \mathrm{L}$ aluminum pan with a small spatula, hermetically sealed, and then loaded onto the DSC instrument at room temperature, using an empty pan of the same type as a reference. Then samples were cooled at $5^{\circ} \mathrm{C} / \mathrm{min}$ to $-60^{\circ} \mathrm{C}$, held for $1 \mathrm{~h}$, and then scanned at $5^{\circ} \mathrm{C}$ $/ \mathrm{min}$ to $20^{\circ} \mathrm{C}$ [19]. The $\mathrm{FW}$ was determined as follows:

$$
F W=\frac{\Delta H m}{\Delta H w}
$$

where $\Delta H w(325 \mathrm{~J} / \mathrm{g})$ is the latent heat of melting per gram of pure water at $0^{\circ} \mathrm{C}[20]$, and $\Delta H(\mathrm{~J} / \mathrm{g})$ is the measured latent heat of melting of water per gram of sample obtained by the integration of the melting endo- thermic peak. The FW amount was expressed as grams per gram of fresh sample weight. Color (CIE L ${ }^{*}=$ lightness, $\mathrm{a}^{*}=$ redness, and $\mathrm{b}^{*}=$ yellowness) [21] was measured in triplicate on the bone-side surface of each fillet using a Chroma Meter CR-400 (Minolta Corp., Milan, Italy).

\subsection{Statistical Analysis}

The effect of marination and heat treatment on quality traits of chicken breasts were evaluated by ANOVA option of the GLM procedure (statistica 6). Means were separated using Duncan test with $\mathrm{P} \leq 0.05$ considered as significant.

\section{Results and Discussion}

\subsection{Effect of Heat Treatment on Proximate Composition}

The effect of heat treatment and marination process together on proximate composition was shown in Table 1. It was found that there were slight differences in ash and lipid contents in chicken breasts marinated with bicarbonate and cooked under different heat treatments (BA, BC, $\mathrm{BD}, \mathrm{BE})$. Low variability in moisture change between different heat treatments could explain the slight differences in ash and fat contents (Table 1), while the lowest moisture content and the highest protein content were observed in the most severe heat treatments for both bicarbonate and phosphate treatments (BE and PE).

Treatment BA and BD had no significant differences in moisture and protein contents. The highest moisture content (71.4\%) among all groups was in $\mathrm{BC}$ treatment. In general, the most severe heat treatment (highest set and core temperature) caused significant higher changes in proximate composition for both types of marinating treatments. The results also showed that breast fillets treated with bicarbonate and cooked at the most severe heat treatment (E) had higher ability to retain water than phosphate treatment $(67.3$ vs $65.7 \%, \mathrm{P}<0.05)$. The effect of heat treatments on the chemical composition of bicarbonate-marinated fillets was different from phosphate-marinated fillets. Overall, both marination and cooking treatments have resulted significant differences in proximate composition which could be explained by different factors: water evaporation, fats melting and loss of soluble proteins [22].

\subsection{Effect of Heat Treatments on Texture Properties}

Changing of heat treatments had significant effect on the texture profile of meat marinated with polyphosphate, while this effect was not clear in the fillets treated with bicarbonate (Tables 2 and 3). Both types of marination 
Table 1. Proximate composition (mean \pm standard error) for chicken breast raw and marinated meat with bicarbonate $(B)$ and phosphate $(P)$ under different heat treatments (A, C, D and $E$ represent different core and oven temperatures: $76-160,80-160,76-200$ and $80^{\circ} \mathrm{C}-200^{\circ} \mathrm{C}$, respectively).

\begin{tabular}{ccccc}
\hline Group & $\begin{array}{c}\text { Total } \\
\text { moisture } \\
(\mathrm{g} / 100 \mathrm{~g})\end{array}$ & $\begin{array}{c}\text { Total } \\
\text { proteins } \\
(\mathrm{g} / 100 \mathrm{~g})\end{array}$ & $\begin{array}{c}\text { Total } \\
\text { lipids } \\
(\mathrm{g} / 100 \mathrm{~g})\end{array}$ & $\begin{array}{c}\text { Total } \\
\text { ash } \\
(\mathrm{g} / 100 \mathrm{~g})\end{array}$ \\
\hline PA & $70.2 \pm 0.4^{\mathrm{b}}$ & $26.9 \pm 0.5^{\mathrm{bcd}}$ & $1.60 \pm 0.30^{\mathrm{ab}}$ & $2.10 \pm 0.07^{\mathrm{ab}}$ \\
PC & $69.9 \pm 0.4^{\mathrm{b}}$ & $27.3 \pm 0.5^{\mathrm{bc}}$ & $1.37 \pm 0.12^{\mathrm{abc}}$ & $1.79 \pm 0.09^{\mathrm{cb}}$ \\
PD & $69.2 \pm 0.4^{\mathrm{b}}$ & $26.8 \pm 0.9^{\mathrm{bcd}}$ & $1.39 \pm 0.09^{\mathrm{abc}}$ & $1.79 \pm 0.06^{\mathrm{cb}}$ \\
PE & $65.7 \pm 0.2^{\mathrm{d}}$ & $31.1 \pm 0.6^{\mathrm{a}}$ & $1.48 \pm 0.17^{\mathrm{ab}}$ & $2.36 \pm 0.26^{\mathrm{c}}$ \\
BA & $70.0 \pm 0.4^{\mathrm{b}}$ & $26.8 \pm 0.6^{\text {cd }}$ & $1.60 \pm 0.13^{\mathrm{ab}}$ & $1.44 \pm 0.07^{\mathrm{d}}$ \\
BC & $71.4 \pm 0.3^{\mathrm{a}}$ & $28.4 \pm 0.7^{\mathrm{b}}$ & $1.70 \pm 0.20^{\mathrm{a}}$ & $1.54 \pm 0.10^{\mathrm{cd}}$ \\
BD & $70.0 \pm 0.4^{\mathrm{b}}$ & $26.7 \pm 0.7^{\text {cd }}$ & $1.31 \pm 0.22^{\mathrm{abc}}$ & $1.60 \pm 0.20^{\mathrm{cd}}$ \\
BE & $67.3 \pm 0.3^{\mathrm{c}}$ & $30.4 \pm 0.6^{\mathrm{a}}$ & $1.59 \pm 0.19^{\mathrm{ab}}$ & $1.76 \pm 0.10^{\mathrm{bcd}}$ \\
\hline
\end{tabular}

${ }^{a-c}$ Different superscript letters within column mean significant difference (P $<0.05)$.

Table 2. Shear force and texture analysis profile (mean \pm standard mean error) of chicken breast meat marinated with phosphate $(P)$ under different heat treatments.

\begin{tabular}{ccccc}
\hline \multirow{2}{*}{ Quality traits } & \multicolumn{4}{c}{ Heat treatment conditions (core-oven temperatures) } \\
\cline { 2 - 5 } & $76-160^{\circ} \mathrm{C}$ & $80-160^{\circ} \mathrm{C}$ & $76-200^{\circ} \mathrm{C}$ & $80-200^{\circ} \mathrm{C}$ \\
$(\mathrm{PA})$ & $(\mathrm{PC})$ & $(\mathrm{PD})$ & $(\mathrm{PE})$ \\
\hline Shear force $(\mathrm{kg} / \mathrm{g})$ & $2.11 \pm 0.10^{\mathrm{c}}$ & $2.08 \pm 0.11^{\mathrm{c}}$ & $2.39 \pm 0.09^{\mathrm{b}}$ & $2.71 \pm 0.10^{\mathrm{a}}$ \\
Hardness $(\mathrm{kg} / \mathrm{g})$ & $2.26 \pm 0.20$ & $2.25 \pm 0.17$ & $1.81 \pm 0.31$ & $2.44 \pm 0.11$ \\
Cohesiveness & $2.78 \pm 0.07^{\mathrm{b}}$ & $2.83 \pm 0.11^{\mathrm{b}}$ & $2.73 \pm 0.11^{\mathrm{b}}$ & $3.12 \pm 0.05^{\mathrm{a}}$ \\
Gumminess $(\mathrm{kg} / \mathrm{g})$ & $6.21 \pm 0.43^{\mathrm{ab}}$ & $6.30 \pm 0.36^{\mathrm{ab}}$ & $4.91 \pm 0.78^{\mathrm{b}}$ & $7.60 \pm 0.29^{\mathrm{a}}$ \\
Springiness & $1.64 \pm 0.05$ & $1.60 \pm 0.04$ & $1.65 \pm 0.04$ & $1.60 \pm 0.04$ \\
Chewiness & $10.1 \pm 0.5^{\mathrm{ab}}$ & $10.0 \pm 0.5^{\mathrm{ab}}$ & $8.0 \pm 1.2^{\mathrm{b}}$ & $12.1 \pm 0.3^{\mathrm{a}}$ \\
\hline
\end{tabular}

${ }^{a-c}$ Different superscript letters within a row mean significant difference $(\mathrm{P}<$ $0.05)$.

Table 3. Shear force and texture analysis profile (mean \pm standard mean error) of chicken breast meat marinated with bicarbonate (B) under different heat treatments.

\begin{tabular}{ccccc}
\hline & \multicolumn{4}{c}{ Heat treatment conditions (core-oven temperatures) } \\
\cline { 2 - 5 } Quality traits & $\begin{array}{c}76-160^{\circ} \mathrm{C} \\
(\mathrm{BA})\end{array}$ & $\begin{array}{c}80-160^{\circ} \mathrm{C} \\
(\mathrm{BC})\end{array}$ & $\begin{array}{c}76-200^{\circ} \mathrm{C} \\
(\mathrm{BD})\end{array}$ & $\begin{array}{c}80-200^{\circ} \mathrm{C} \\
(\mathrm{BE})\end{array}$ \\
\hline Shear force $(\mathrm{kg} / \mathrm{g})$ & $2.52 \pm 0.09^{\mathrm{ab}}$ & $2.41 \pm 0.13^{\mathrm{b}}$ & $2.59 \pm 0.14^{\mathrm{ab}}$ & $2.85 \pm 0.09^{\mathrm{a}}$ \\
Hardness $(\mathrm{kg} / \mathrm{g})$ & $2.44 \pm 0.13$ & $2.25 \pm 0.27$ & $2.03 \pm 0.12$ & $1.88 \pm 0.11$ \\
Cohesiveness & $2.87 \pm 0.09$ & $3.16 \pm 0.13$ & $2.94 \pm 0.06$ & $3.11 \pm 0.11$ \\
Gumminess $(\mathrm{kg} / \mathrm{g})$ & $6.92 \pm 0.22$ & $7.01 \pm 0.78$ & $5.97 \pm 0.35$ & $5.79 \pm 0.32$ \\
Springiness & $1.48 \pm 0.04^{\mathrm{ab}}$ & $1.44 \pm 0.03^{\mathrm{b}}$ & $1.54 \pm 0.04^{\mathrm{ab}}$ & $1.56 \pm 0.02^{\mathrm{a}}$ \\
Chewiness & $10.25 \pm 0.39$ & $10.04 \pm 1.00$ & $9.14 \pm 0.53$ & $9.05 \pm 0.48$
\end{tabular}

${ }^{a-b}$ Different superscript letters within a row mean significant difference $(\mathrm{P}<$ $0.05)$.

treatment did not show any change in hardness (resistance to deformation) at different heat treatment conditions (Tables 2 and 3). The effect of heat treatment was significant in PE treatment, where cohesiveness (the strength of the internal bonds making up the product), gumminess (the energy required to disintegrate a semisolid food to a state ready for swallowing), and chewiness (a low resistance to breakdown on mastication) values were significantly $(\mathrm{P}<0.05)$ increased (Table 2$)$.

It is known that during marination process using phosphates, myofibrillar proteins are extracted on the surface of meat. The extracted proteins have two functions during cooking process. First, they improve binding properties by coagulation. The second, they facilitate the retention of moisture in the meat tissue by sealing the micro-capillaries with coagulated proteins [23]. It is not known if marinated meat with bicarbonate shows the same behavior in comparison with phosphate-marinated meat. But in general, the higher water holding capacity and swelling of myofibrils are responsible about the mechanism of increased tenderness and juiciness [24]. Effect of bicarbonate on the texture properties needs further investigations.

Both type of marination treatments showed higher shear values in the most severe heat treatments (PE and $\mathrm{BE})$. Heat treatments changed the elasticity of fillets treated with bicarbonate as represented by springiness values (Table 2).

The effect of heat treatments on the texture profile of bicarbonate-marinated fillets was less than phosphatemarinated fillets; this could be explained due to the generation of carbon dioxide produced during cooking and formation of air-filled pockets which could dilute the load-bearing material during the texture analysis [25].

Moreover, the lower hardness values (softness) could be attributed to the large amount of water retained in the meat. The role of phosphate in improving the tenderness of meat is known. Polyphosphates promote the weakening of the myosin heads to actin, and thus promote the dissociation of actomyosin, increase the electrostatic charge and therefore, they could allow more water to be retained or taken up by the meat. The increased tenderness might be attributed directly to the higher water content and weakened muscle structure [4].

\subsection{Water Activity, Freezable and Bound Water}

There are three different forms of water inside the meat tissues. The first one is the major part of water (more than $80 \%$ ) retained in meat as free which can be expressed by water activity $\left(a_{w}\right)$. The second part of water $(10 \%-15 \%)$ is immobilized and entrapped under the effect of net charge attraction. The third part of water is a minor part (around 4\%) usually bound to the ionizable groups of amino acids of the proteins and other groups able to form $\mathrm{H}$ bonds [26]. The first two parts of water are affected or lost during processing like cooking, cut- 
ting, grinding, and storage. In our study, water activity $\left(a_{\mathrm{w}}\right)$ was used to estimate mainly the first two parts.

$a_{\mathrm{w}}$ was significantly higher in bicarbonate treated fillets when compared to phosphate marinated fillets $(0.998$ vs $0.995, \mathrm{P}<0.05)$. Water activity was reduced after cooking in all type of heat treatments in comparison to raw marinated meat (Figures 1 and 2) which may be explained by loss of major amount of free water due to evaporation by dry cooking. The most severe heat treatment $\left(80^{\circ} \mathrm{C}-200^{\circ} \mathrm{C}\right)$ exhibited the lowest $a_{\mathrm{w}}$ for both types of marination treatments.

There were no significant differences in water activity after marination process for both types of treatments in comparison to raw meat. Phosphate-marinated fillets showed the same trend in the change of water activity during different cooking treatments. The effect of core temperature on water activity was stronger than the effect of oven temperature in both of marination treatments.

There were significant differences in total latent heat and bound water among bicarbonate-marinated and phosphate-marinated fillets (Table 4). Bicarbonate-marinated fillets cooked at $76^{\circ} \mathrm{C}-200^{\circ} \mathrm{C}$ exhibited the highest $(\mathrm{P}<0.05)$ percentage of bound water $(18.1 \%)$.

Marination process had minor effect on bound water for bicarbonate-marinated and phosphate-marinated fillets in comparison to raw fillets. Cooking treatments A, $\mathrm{C}$ and D for phosphate-marinated fillets showed slight significant differences in bound water. Phosphate-marinated fillets cooked by heat treatment $\left(\mathrm{E}: 80^{\circ} \mathrm{C}-200^{\circ} \mathrm{C}\right)$ showed lowest latent heat value $(160 \mathrm{~J} / \mathrm{g})$ and highest bound water percentage $(25.0 \%)$ in comparison with other groups.

The freezable water content for raw fillets was about $93 \%$ of the total amount, while after marination it was $91 \%$ and $90 \%$ for phosphate and bicarbonate-marinated fillets respectively. The change in freezable water content after marination was slightly significant for both types of treatments. There were significant differences in freezable water after cooking in all groups of treatment but in different degrees (Figure 3). The most severe heat treatment $\left(80^{\circ} \mathrm{C}-200^{\circ} \mathrm{C}\right)$ for phosphate-marinated fillets showed the lowest value $(0.75)$ of freezable water. According to these results there was no relation between freezable water values and water activity values. Changing the percentage of freezable and bound water during different cooking could be attributed to the loss of water by evaporation, loss of some soluble proteins due to cooking loss, and denaturation of proteins in which the type or the forms of bonds with water change.

\subsection{Color, pH, Marinade Uptake, Drip and Cooking Loss and WHC (Pooled as Marination)}

There were no significant differences in $\mathrm{L}^{*}$ (lightness),

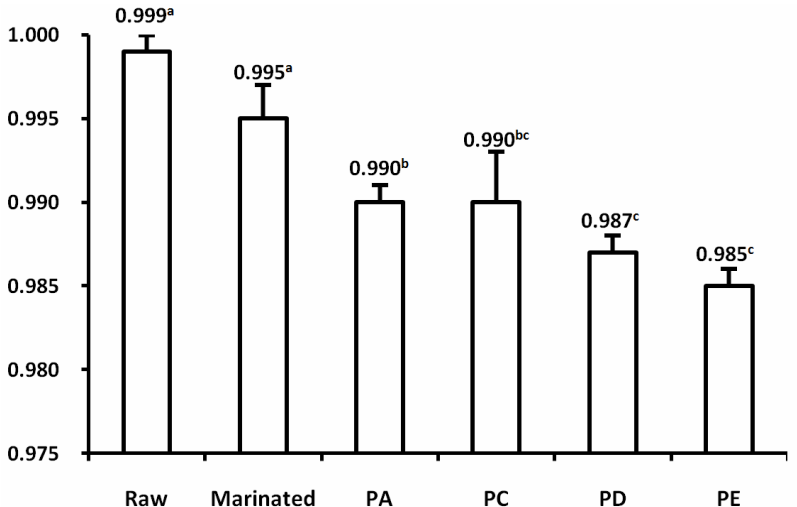

Figure 1. Water activity $a_{w}$ (mean \pm standard mean error) for chicken breast meat raw and marinated with phosphate (P) and cooked at different heat treatments $(A, C, D$ and $E$ represent different core and oven temperatures: 76 - 160, 80 160, $76-200$ and $80-200^{\circ} \mathrm{C}$, respectively) ${ }^{\mathrm{a}-\mathrm{c}}$ Different superscript letters mean significant difference $(\mathrm{P}<0.05)$.

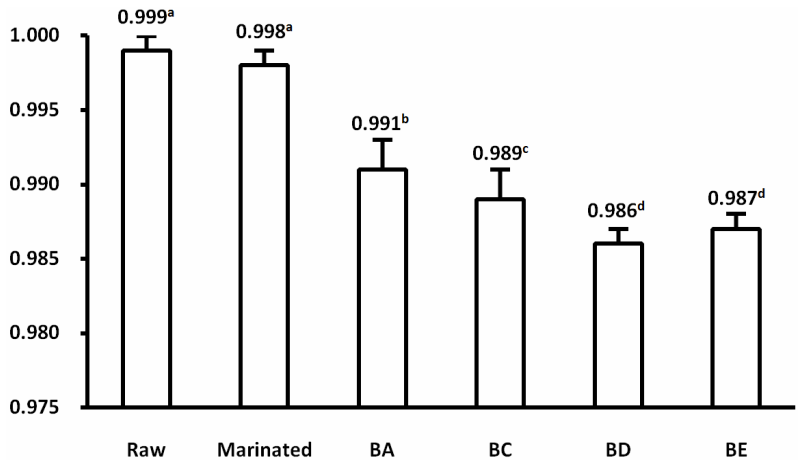

Figure 2. Water activity $\left(a_{w}\right)$ (mean \pm standard mean error) for chicken breast meat raw and marinated with bicarbonate $(B)$ and cooked at different heat treatments (A, C, D and $E$ represent different core and oven temperatures: 76 $160,80-160,76-200$ and $80-200^{\circ} \mathrm{C}$, respectively). ${ }^{\mathrm{a}-\mathrm{d}}$ Different superscript letters mean significant difference $(P<$ 0.05).

Table 4. The results of enthalpy and bound water (mean \pm standard mean error) of chicken breast meat marinated with bicarbonate and phosphate.

\begin{tabular}{ccccc}
\hline & \multicolumn{2}{c}{ Phosphate } & \multicolumn{2}{c}{ Bicarbonate } \\
\hline & $\begin{array}{c}\text { Bound } \\
\text { water } \\
(\%)\end{array}$ & $\begin{array}{c}\text { Latent } \\
\text { heat } \\
(\mathrm{J} / \mathrm{g})\end{array}$ & $\begin{array}{c}\text { Bound } \\
\text { water } \\
(\%)\end{array}$ & $\begin{array}{c}\text { Latent } \\
\text { heat } \\
(\mathrm{J} / \mathrm{g})\end{array}$ \\
\hline Before marination & $7.2 \pm 0.70^{\mathrm{c}}$ & $224.7 \pm 1.8^{\mathrm{ab}}$ & $7.2 \pm 0.7^{\mathrm{c}}$ & $224.7 \pm 1.8^{\mathrm{a}}$ \\
After marination & $9.1 \pm 3.7^{\mathrm{bc}}$ & $230.2 \pm 9.4^{\mathrm{a}}$ & $10.4 \pm 4.1^{\mathrm{abc}}$ & $227.6 \pm 10.4^{\mathrm{a}}$ \\
$\mathrm{A}\left(76-160^{\circ} \mathrm{C}\right)$ & $10.8 \pm 4.7^{\mathrm{bc}}$ & $203.4 \pm 10.8^{\mathrm{bc}}$ & $7.0 \pm 1.9^{\mathrm{c}}$ & $211.5 \pm 4.3^{\mathrm{a}}$ \\
$\mathrm{C}\left(80-160^{\circ} \mathrm{C}\right)$ & $21.8 \pm 2.2^{\mathrm{a}}$ & $177.7 \pm 5.0^{\text {de }}$ & $9.2 \pm 3.4^{\mathrm{bc}}$ & $210.2 \pm 7.8^{\mathrm{a}}$ \\
$\mathrm{D}\left(76-200^{\circ} \mathrm{C}\right)$ & $18.1 \pm 1.8^{\mathrm{ab}}$ & $184.3 \pm 4.0^{\text {cd }}$ & $18.1 \pm 3.1^{\mathrm{a}}$ & $186.8 \pm 7.0^{\mathrm{b}}$ \\
$\mathrm{E}\left(80-200^{\circ} \mathrm{C}\right)$ & $25.0 \pm 3.8^{\mathrm{a}}$ & $160.0 \pm 8.1^{\mathrm{e}}$ & $16.1 \pm 0.7^{\mathrm{ab}}$ & $183.5 \pm 1.6^{\mathrm{b}}$ \\
\hline
\end{tabular}

${ }^{\mathrm{a}-\mathrm{e}}$ Different superscript letters within a row mean significant difference $(\mathrm{P}<$ $0.05)$. 


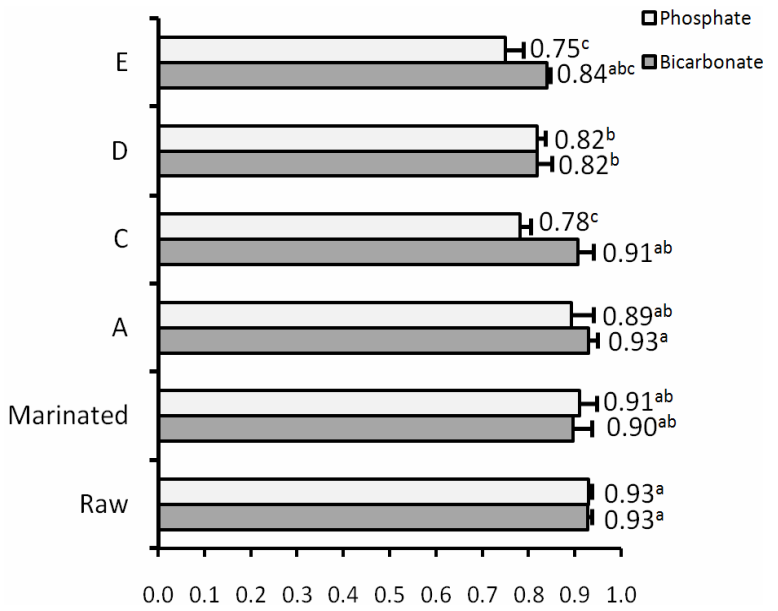

Figure 3. Freezable water (mean \pm standard mean error) for chicken breast meat raw and marinated with phosphate and bicarbonate and cooked at different heat treatments $(A$, $C, D$ and $E$ represent different core and oven temperatures: $76-160,80-160,76-200$ and $80-200^{\circ} \mathrm{C}$, respectively). ${ }^{\mathrm{a}-\mathrm{c}}$ Different superscript letters mean significant difference $(\mathbf{P}<\mathbf{0 . 0 5})$.

$\mathrm{a}^{*}$ (redness) and $\mathrm{b}^{*}$ (yellowness) values of raw meat chicken fillets which were dedicated for bicarbonate and phosphate treatments. The samples were dispersed in systematic way to obtain consistency of color between treatment groups. The consistency in the color is important because meat color extremes have been shown to affect marination uptake, cook yield, and texture [27]. After marination process, $L^{*}$ (Lightness) values for bicarbonate (55.3 vs. 51.0) and phosphate (56.5 vs. 50.9) treatments were significantly $(\mathrm{P}<0.05)$ increased in comparison to raw fillets while there were no significant differences in $\mathrm{a}^{*}$ and $\mathrm{b}^{*}$ values (Table 5). This increase in lightness could be due to the increase in extracellular water as a result of the marination process. In general, there was no consensus between the previous studies on the effect of marination process on the color values. Young et al. [28] found similar $\mathrm{L}^{*}, \mathrm{a}^{*}$ and lower $\mathrm{b}^{*}$ values in marinated fillets in comparison to non-marinated fillets, while Lyon et al. [29] pointed out that marinated poultry muscles were less red $\left(a^{*}\right)$ and less yellow $\left(b^{*}\right)$ when compared to non-marinated meat. In another study, marinated meat showed slight significant decrease in $\mathrm{L}^{*}$ and $\mathrm{a}^{*}$ values [30]. It was found that both $\mathrm{a}^{*}$ and $\mathrm{b}^{*}$ values were decreased in marinated fillets [31,32]. It is not easy to resolve the changes in the color values of poultry muscle after marination because they depend on different factors, but the most important is the $\mathrm{pH}$ [33]. It was found also that vacuum tumble marination has resulted to increase cooked meat lightness and decrease cooked meat redness [34].

As expected, meat $\mathrm{pH}$ was increased after both types
Table 5. Color values, pH, marinade uptake, drip loss, WHC and cooking loss (mean \pm standard error) for raw and cooked chicken breast meat marinated with bicarbonate and phosphate (pooled as marination treatment).

\begin{tabular}{cccc}
\hline & & \multicolumn{2}{c}{ Marination treatment } \\
\hline \multicolumn{2}{c}{ Quality traits } & Phosphate & Bicarbonate \\
\hline $\mathrm{L}^{*}$ & raw & $50.9 \pm 0.2^{\mathrm{x}}$ & $51.0 \pm 0.2^{\mathrm{x}}$ \\
& marinade & $56.5 \pm 0.4^{\mathrm{a} ; \mathrm{y}}$ & $55.3 \pm 0.3^{\mathrm{b} ; \mathrm{y}}$ \\
$\mathrm{a}^{*}$ & raw & $0.77 \pm 0.08$ & $0.46 \pm 0.08$ \\
& marinade & $0.84 \pm 0.10^{\mathrm{a}}$ & $0.33 \pm 0.09^{\mathrm{b}}$ \\
$\mathrm{b}^{*}$ & raw & $9.55 \pm 0.24$ & $9.50 \pm 0.24$ \\
& marinade & $10.19 \pm 0.32^{\mathrm{a}}$ & $9.05 \pm 0.28^{\mathrm{b}}$ \\
$\mathrm{pH}$ & raw & $5.92 \pm 0.02^{\mathrm{x}}$ & $5.92 \pm 0.02^{\mathrm{x}}$ \\
& marinade & $6.07 \pm 0.01^{\mathrm{b}, \mathrm{y}}$ & $6.26 \pm 0.02^{\mathrm{a}, \mathrm{y}}$ \\
& cooked & $6.15 \pm 0.01^{\mathrm{b}, \mathrm{y}}$ & $6.24 \pm 0.01^{\mathrm{a}, \mathrm{y}}$ \\
Marinade uptake (\%) & $16.0 \pm 0.4^{\mathrm{b}}$ & $17.3 \pm 0.3^{\mathrm{a}}$ \\
\multicolumn{2}{c}{ Drip loss (\%) } & $2.74 \pm 0.10^{\mathrm{b}}$ & $3.24 \pm 0.11^{\mathrm{a}}$ \\
\multicolumn{2}{c}{ WHC (\%) } & $-2,38 \pm 1.61$ & $-2.43 \pm 1.05$ \\
Cooking loss (\%) & $27.0 \pm 0.8$ & $26.3 \pm 0.5$ \\
\hline
\end{tabular}

${ }^{\mathrm{a}-\mathrm{b}}$ Different superscript letters within a row mean significant difference $(\mathrm{P}<$ $0.05) .{ }^{\mathrm{x}-\mathrm{y}}$ Different superscript letters within a column mean significant difference $(\mathrm{P}<0.05)$.

of marination treatment because both marinating ingredients are alkaling agents. Phosphate alone increased significantly $(\mathrm{P}<0.05)$ meat $\mathrm{pH}$ by approximately 0.15 units, whilst bicarbonate alone increased the $\mathrm{pH}$ by 0.34 units (Table 5). Bicarbonate showed higher effect on the $\mathrm{pH}$ than phosphate and these results are in consistent with the previous studies [35]. The differences in buffering capacity and ionic strength between phosphate and bicarbonate may be explain the difference in the ultimate $\mathrm{pH}$ [36]. The greater effect of bicarbonates may be due to a higher buffering capacity and ionic strength than phosphates.

The $\mathrm{pH}$ of meat treated with bicarbonate and phophate was not affected after cooking. This result was not in agreement with Sindelar et al. [37] who found that the $\mathrm{pH}$ of marinated sow loins with bicarbonate and polyphosphate increased after cooking. Bicarbonate-marinated fillets had significantly $(\mathrm{P}<0.05)$ higher values of marinade uptake $(17.3 \%$ vs. $16.0 \%)$ and drip loss $(3.24 \%$ vs. $2.74 \%$ ) in comparison with phosphate-marinated fillets respectively.

Joo et al. [38] found that drip loss was correlated with protein solubility, increase the solubility of myofibrillar, sarcoplasmic, and total proteins reduced the drip loss. The causes of the difference in the drip loss between phosphate and bicarbonate are not known, and so the protein solubility should be evaluated when bicarbonate uses in comparison to phosphate.

The increase in marinade uptake can be attributed to the increased net negative charge associated to bicarbo- 
nate. Water holding capacity and cooking loss did not show any significant differences among the treatments (Table 5).

When the results of cooking loss were pooled taking in consideration just effect of marination process, there were no significant differences in the cooking loss, while the differences were present when the results were classified according to the type of heat treatment.

\subsection{Effect of Heat Treatments on the Color and pH Values}

Because the $\mathrm{pH}$ has great impact on tenderness, color, WHC and meat protein binding ability; raw chicken fillets were distributed in a way to obtain no significant differences in the initial $\mathrm{pH}$ and lightness $\left(\mathrm{L}^{*}\right)$ among different groups of treatments (Table 6). Lightness was significantly $(\mathrm{P}<0.05)$ increased after marination and after cooking in all treatment groups of bicarbonate-marinated and phosphate-marinated fillets. Even all groups of each treatment (bicarbonate or phosphate) were separately marinated in one batch; they showed different lightness values between groups within the same batch after marination and after cooking. In general, bicarbonate-marinated fillets cooked under different heat treatments exhibited slightly higher lightness values than phosphate-marinated fillets; in spite of that, bicarbonate shifts the $\mathrm{pH}$ higher than phosphate and also it is well known that meat with high ultimate $\mathrm{pH}$ will appear darker because its surface scatters less light than meat with a low ultimate $\mathrm{pH}$ [39]. Nevertheless, the color of bicarbonate-marinated fillets became lighter.

Redness $\left(\mathrm{a}^{*}\right)$ and yellowness (b) values did not change after marination in all the groups of treatment. On another hand, after cooking redness $\left(\mathrm{a}^{*}\right)$ and yellowness (b) values were significantly $(\mathrm{P}<0.05)$ increased in all groups (Table 6). These results are in agreement with Resurrección [40] who found that the marinated cooked samples were generally lighter (higher $\mathrm{L}^{*}$ ) and more yellow (higher $\mathrm{b}^{*}$ ), whereas $\mathrm{a}^{*}$ (red color) increased as temperature and cooking time increased.

The increase in lightness $\left(\mathrm{L}^{*}\right)$ values after cooking could be explained by meat proteins denaturation during heating process which leads to increased the reflection and scattering of light giving more lighter meat [34], while the increase in redness $\left(\mathrm{a}^{*}\right)$ and yellowness $(\mathrm{b})$ values in all groups could be explained by sugar-amine browning reaction that occurs on the dehydrated surface due to the dry heating, amine groups in the muscle proteins react with any available reducing sugars, such as free glucose, giving brown color derivatives. Browning occurs normally at high temperatures (more than $90^{\circ} \mathrm{C}$ ); in our experiment the surface temperature was higher than $160^{\circ} \mathrm{C}$. Another cause which may change redness $\left(\mathrm{a}^{*}\right)$ and yellowness $\left(\mathrm{b}^{*}\right)$ values is formation of cooked meat pigments which show the brown color of metmyoglobin because of oxidation and denaturation of globular protein from heat [41]. Redness $\left(\mathrm{a}^{*}\right)$ values for bicarbonate-marinated fillet were slightly higher than phosphate-marinated fillets. Trout [42] pointed out that increase the $\mathrm{pH}$ of the meat decreased heat denaturation of myoglobin during cooking, therefore resulting to increase pinkness or redness value. He observed also that the phosphate ion increases the susceptibility of myoglobin to heat denaturation, but the increase of $\mathrm{pH}$ due to the addition of tripolyphosphate compensates the effect of susceptibility to denaturation.

\subsection{Marinade Uptakes, Drip Loss, Cooking Loss and Yield versus Heat Treatments}

There were no significant differences in marinade uptake and drip loss among the groups assigned for different cooking conditions for both of bicarbonate and phosphate-marinated treatments. The most severe heat treatment $\left(80^{\circ} \mathrm{C}-200^{\circ} \mathrm{C}\right)$ showed the highest cooking loss $(30.68 \%$ and $33.43 \% ; \mathrm{P}<0.05)$ and the lowest yield $(69.32 \%$ and $66.57 \%$; $\mathrm{P}<0.05)$ for both type of bicarbonate and phosphate-marinated treatments respectively (Table 7). At this type of heat treatment, bicarbonate-marinated fillets showed higher ability to retain the moisture than phosphate which can be seen by the results of cooking loss and yield. The rest of the heat treatment did not show any effect on cooking loss and yield in all of the groups.

By and large, fillets treated with bicarbonate showed higher ability to retain water in comparison of phosphates. Actin (thin filament), myosin (thick filament), and their combined structure actomyosin are the most important protein which play a major role in water binding capacity. Phosphates solubilize and unfold myofibrillar proteins due to electrostatic repulsion, and so more the amount of water that can be retained by the muscle due to increase the size of the space between filaments. Therefore, anything that changes the spaces between the thick and thin filaments or the ability of the proteins to bind water can affect water-holding properties of the meat $[39,43]$. The roles of phosphates in improving the water binding are well known and they work in different ways: due to their buffering capacity phosphates are able to shift $\mathrm{pH}$ far away from the isoelectric point of the myofibrillar proteins, unfolding muscle proteins which lead to more charged sites for water binding, and cleavage actomyosin bonds that formed in post rigor, thereby increasing the potential for swelling of the filaments [4].

On another hand, the exact mechanisms for the roles of bicarbonate in improving the water binding-holding capacity are not well known. In our results, bicarbonate 
Table 6. Color and pH values (mean \pm standard error) of chicken breast meat marinated with bicarbonate (B) and phosphate (P) cooked under different heat treatments (A, C, D and E represent different core and oven temperatures: 76 - 160, 80 - 160, $76-200$ and $80-200^{\circ} \mathrm{C}$, respectively).

\begin{tabular}{|c|c|c|c|c|c|c|c|c|}
\hline \multirow{2}{*}{$\begin{array}{l}\text { Quality } \\
\text { trait }\end{array}$} & \multicolumn{4}{|c|}{ Phosphate } & \multicolumn{4}{|c|}{ Bicarbonate } \\
\hline & $\begin{array}{c}76^{\circ} \mathrm{C}-160^{\circ} \mathrm{C} \\
\text { (PA) }\end{array}$ & $\begin{array}{c}80^{\circ} \mathrm{C}-160^{\circ} \mathrm{C} \\
\text { (PC) }\end{array}$ & $\begin{array}{c}76^{\circ} \mathrm{C}-200^{\circ} \mathrm{C} \\
\text { (PD) }\end{array}$ & $\begin{array}{c}80^{\circ} \mathrm{C}-200^{\circ} \mathrm{C} \\
(\mathrm{PE})\end{array}$ & $\begin{array}{c}76^{\circ} \mathrm{C}-160^{\circ} \mathrm{C} \\
\text { (BA) }\end{array}$ & $\begin{array}{c}80^{\circ} \mathrm{C}-160^{\circ} \mathrm{C} \\
\text { (BC) }\end{array}$ & $\begin{array}{c}76^{\circ} \mathrm{C}-200^{\circ} \mathrm{C} \\
\text { (BD) }\end{array}$ & $\begin{array}{c}80^{\circ} \mathrm{C}-200^{\circ} \mathrm{C} \\
(\mathrm{BE})\end{array}$ \\
\hline $\mathrm{L}_{\text {raw }}^{*}$ & $51.0 \pm 0.9^{x}$ & $50.4 \pm 0.9^{x}$ & $51.7 \pm 0.7^{x}$ & $50.6 \pm 0.9^{x}$ & $49.8 \pm 1.1^{\mathrm{x}}$ & $52.2 \pm 0.8^{x}$ & $51.6 \pm 0.4^{x}$ & $50.5 \pm 0.7^{x}$ \\
\hline $\mathrm{L}_{\text {marinade }}^{*}$ & $56.7 \pm 0.7^{\mathrm{abc} ; \mathrm{y}}$ & $54.5 \pm 0.7^{\mathrm{c} ; \mathrm{y}}$ & $57.3 \pm 0.4^{\mathrm{ab} ; \mathrm{y}}$ & $57.5 \pm 0.7^{\mathrm{a} ; \mathrm{y}}$ & $55.2 \pm 0.9^{\mathrm{bc} ; \mathrm{y}}$ & $54.6 \pm 0.6^{\mathrm{c} ; \mathrm{y}}$ & $55.6 \pm 0.6^{\mathrm{abc} ; \mathrm{y}}$ & $55.8 \pm 0.7^{\mathrm{abc} ; \mathrm{y}}$ \\
\hline $\mathrm{L}_{\text {cooked }}^{*}$ & $77.0 \pm 0.5^{\mathrm{c} ; \mathrm{z}}$ & $78.7 \pm 0.7^{\mathrm{abc} ; \mathrm{z}}$ & $77.1 \pm 0.8^{\mathrm{c} ; \mathrm{z}}$ & $78.0 \pm 0.8^{\mathrm{bc}}$ & $77.5 \pm 0.6^{\mathrm{bc} ; \mathrm{z}}$ & $79.3 \pm 0.6^{\mathrm{ab} ; \mathrm{z}}$ & $79.3 \pm 0.5^{\mathrm{ab}}$ & $80.0 \pm 0.3^{\mathrm{a} ; \mathrm{z}}$ \\
\hline $\mathrm{a}_{\text {raw }}^{*}$ & $0.91 \pm 0.34^{\mathrm{x}}$ & $0.82 \pm 0.10$ & $0.72 \pm 0.25^{\mathrm{x}}$ & $0.62 \pm 0.21^{\mathrm{x}}$ & $0.98 \pm 0.27^{\mathrm{x}}$ & $-0.06 \pm 0.34^{\mathrm{x}}$ & $0.65 \pm 0.21^{\mathrm{x}}$ & $0.28 \pm 0.20^{\mathrm{x}}$ \\
\hline $\mathrm{a}_{\text {marinade }}^{*}$ & $0.77 \pm 0.27^{\mathrm{ab} ; \mathrm{x}}$ & $0.96 \pm 0.12^{\mathrm{a} ; \mathrm{x}}$ & $0.91 \pm 0.19^{\mathrm{a} ; \mathrm{x}}$ & $0.71 \pm 0.18^{\mathrm{ab} ; \mathrm{x}}$ & $0.50 \pm 0.23^{\mathrm{abc} ; \mathrm{x}}$ & $0.10 \pm 0.32^{\mathrm{bc} ; \mathrm{x}}$ & $0.89 \pm 0.32^{\mathrm{a}}$ & $-0.19 \pm 0.14^{\mathrm{c} ; \mathrm{x}}$ \\
\hline$a_{\text {cooked }}^{*}$ & $2.13 \pm 0.16^{\mathrm{cde} ; \mathrm{y}}$ & $2.39 \pm 0.14^{\text {bcd;y }}$ & $2.73 \pm 0.14^{\mathrm{ab} ; \mathrm{y}}$ & $1.69 \pm 0.15^{\mathrm{e} ; \mathrm{y}}$ & $2.65 \pm 0.24^{\mathrm{abc} ; \mathrm{y}}$ & $2.20 \pm 0.24^{\text {bcde;y }}$ & $2.93 \pm 0.16^{\mathrm{a} ; \mathrm{y}}$ & $1.85 \pm 0.20^{\mathrm{de} ; \mathrm{y}}$ \\
\hline $\mathrm{b}_{\text {raw }}^{*}$ & $10.46 \pm 0.88^{\mathrm{x}}$ & $8.42 \pm 0.73^{x}$ & $9.77 \pm 0.62^{x}$ & $9.53 \pm 0.64^{x}$ & $8.19 \pm 0.79^{x}$ & $10.88 \pm 0.66^{\mathrm{x}}$ & $8.84 \pm 0.86^{x}$ & $10.07 \pm 0.95^{\mathrm{x}}$ \\
\hline $\mathrm{b}_{\text {marinade }}^{*}$ & $11.02 \pm 0.98^{\mathrm{a} ; \mathrm{xy}}$ & $8.20 \pm 0.18^{\mathrm{b} ; \mathrm{x}}$ & $10.77 \pm 0.40^{\mathrm{a} ; \mathrm{x}}$ & $10.77 \pm 0.39^{\mathrm{a} ; \mathrm{x}}$ & $8.10 \pm 0.86^{\mathrm{b} ; \mathrm{x}}$ & $10.07 \pm 0.61^{\mathrm{ab} ; \mathrm{x}}$ & $9.04 \pm 0.78^{\mathrm{ab} ; \mathrm{x}}$ & $8.99 \pm 0.83^{\mathrm{ab} ; \mathrm{x}}$ \\
\hline $\mathrm{b}_{\text {cooked }}^{*}$ & $13.3 \pm 0.8^{\mathrm{y}}$ & $14.0 \pm 0.3^{\mathrm{y}}$ & $14.6 \pm 0.4^{\mathrm{y}}$ & $14.6 \pm 0.6^{\mathrm{y}}$ & $13.2 \pm 0.6^{\mathrm{y}}$ & $14.9 \pm 0.6^{\mathrm{y}}$ & $15.3 \pm 0.5^{\mathrm{y}}$ & $14.9 \pm 0.5^{\mathrm{y}}$ \\
\hline $\mathrm{pH}_{\text {raw }}$ & $5.92 \pm 0.02^{x}$ & $5.92 \pm 0.02^{\mathrm{x}}$ & $5.92 \pm 0.02^{x}$ & $5.92 \pm 0.02^{\mathrm{x}}$ & $5.92 \pm 0.02^{x}$ & $5.92 \pm 0.02^{x}$ & $5.92 \pm 0.02^{\mathrm{x}}$ & $5.92 \pm 0.02^{\mathrm{x}}$ \\
\hline $\mathrm{pH}_{\text {cooked }}$ & $6.16 \pm 0.02^{\mathrm{d} ; \mathrm{y}}$ & $6.17 \pm 0.02^{\mathrm{bd} ; \mathrm{y}}$ & $6.14 \pm 0.02^{\mathrm{d} ; \mathrm{y}}$ & $6.14 \pm 0.01^{\mathrm{d} ; \mathrm{y}}$ & $6.23 \pm 0.03^{\mathrm{abc} ; \mathrm{y}}$ & $6.28 \pm 0.04^{\mathrm{a} ; \mathrm{y}}$ & $6.21 \pm 0.02^{\text {bcd;y }}$ & $6.24 \pm 0.02^{\mathrm{abc} ; \mathrm{y}}$ \\
\hline
\end{tabular}

${ }^{\mathrm{a}-\mathrm{e}}$ Different superscript letters within a row mean significant difference $(\mathrm{P}<0.05) .{ }^{\mathrm{x}-\mathrm{z}}$ Different superscript letters within a column mean significant difference $(\mathrm{P}$ $<0.05)$.

Table 7. Marinade uptake, drip loss, cooking loss and yield (mean \pm standard error) of chicken breast meat marinated with bicarbonate $(B)$ and phosphate $(P)$ cooked under different heat treatments $(A, C, D$ and $E$ represent different core and oven temperatures: $76-160,80-160,76-200$ and $80-200^{\circ} \mathrm{C}$, respectively).

\begin{tabular}{|c|c|c|c|c|c|c|c|c|}
\hline \multirow[b]{2}{*}{ Quality traits } & \multicolumn{4}{|c|}{ Phosphate } & \multicolumn{4}{|c|}{ Bicarbonate } \\
\hline & $\begin{array}{c}76^{\circ} \mathrm{C}-160^{\circ} \mathrm{C} \\
(\mathrm{PA})\end{array}$ & $\begin{array}{c}80^{\circ} \mathrm{C}-160^{\circ} \mathrm{C} \\
\text { (PC) }\end{array}$ & $\begin{array}{c}76^{\circ} \mathrm{C}-200^{\circ} \mathrm{C} \\
(\mathrm{PD})\end{array}$ & $\begin{array}{c}80^{\circ} \mathrm{C}-200^{\circ} \mathrm{C} \\
(\mathrm{PE})\end{array}$ & $\begin{array}{c}76^{\circ} \mathrm{C}-160^{\circ} \mathrm{C} \\
\text { (BA) }\end{array}$ & $\begin{array}{c}80^{\circ} \mathrm{C}-160^{\circ} \mathrm{C} \\
(\mathrm{BC})\end{array}$ & $\begin{array}{c}76^{\circ} \mathrm{C}-200^{\circ} \mathrm{C} \\
\text { (BD) }\end{array}$ & $\begin{array}{c}80^{\circ} \mathrm{C}-200^{\circ} \mathrm{C} \\
(\mathrm{BE})\end{array}$ \\
\hline Marinade uptake (\%) & $16.2 \pm 0.8$ & $14.7 \pm 0.7$ & $16.7 \pm 0.9$ & $16.5 \pm 0.8$ & $16.2 \pm 0.6$ & $17.2 \pm 0.8$ & $18.1 \pm 0.9$ & $17.6 \pm 0.9$ \\
\hline Cooking loss (\%) & $25.2 \pm 0.6^{\mathrm{c}}$ & $24.4 \pm 0.6^{\mathrm{c}}$ & $25.0 \pm 1.7^{\mathrm{c}}$ & $33.4 \pm 0.5^{\mathrm{a}}$ & $24.6 \pm 0.5^{\mathrm{c}}$ & $25.4 \pm 0.8^{\mathrm{c}}$ & $24.6 \pm 0.7^{\mathrm{c}}$ & $30.7 \pm 0.6^{\mathrm{b}}$ \\
\hline Yield (\%) & $74.8 \pm 0.6^{\mathrm{a}}$ & $75.6 \pm 0.6^{\mathrm{a}}$ & $74.9 \pm 1.8^{\mathrm{a}}$ & $66.6 \pm 0.5^{\mathrm{c}}$ & $75.4 \pm 0.5^{\mathrm{a}}$ & $74.6 \pm 0.8^{\mathrm{a}}$ & $75.3 \pm 0.7^{\mathrm{a}}$ & $69.3 \pm 0.6^{\mathrm{b}}$ \\
\hline
\end{tabular}

${ }^{\mathrm{a}-\mathrm{c}}$ Different superscript letters within a row mean significant difference $(\mathrm{P}<0.05)$.

exhibited higher water binding capacity than phosphates which could be explained because bicarbonate increased more the $\mathrm{pH}$ and showed higher ionic strength [10]. Therefore it could increase the spaces between the thick and thin filaments more than phosphate. Sodium bicarbonate also produced holes during cooking due to generation of carbon dioxide leading to coarser microstructure which could also improve the physical entrapment of water [44].

\section{Conclusion}

Chicken breast fillets treated with phosphates exhibited different quality traits (texture profile analysis, shear force, water activity, freezable water and chemical compositions) when compared with fillets treated with bicarbonate. Bicarbonate-marinated fillet showed better water binding capacity and texture properties. The exact roles that stand behind these differences between bicarbonate and phosphate are not well known, but the main discriminated feature of bicarbonate is the ability to raise the $\mathrm{pH}$ higher than phosphate and generation of carbon dioxide gases during cooking. The findings of this study suggest that phosphate marinated fillets interact with heat treatments in different way in comparison with bicarbonate manated fillets. Overall, bicarbonate could be a promising agent to replace phosphate in meat formulation buthere is a necessity to evaluate the use of bicarbonate der different processing conditions and formulations.

\section{REFERENCES}

[1] C. Alavardo and S. Mckee, "Marination to Improve Functional Properties and Safety of Poultry Meat," Journal of Applied Poultry Research, Vol. 16, No. 1, 2007, pp. 113120.

[2] M. Zheng, A. Detienne, W. Barnes and L. Wicker, "Tenderness and Yields of Poultry Breast Are Influenced by Phosphate Type and Concentration of Marinade," Journal of Agricultural and Food Chemistry, Vol. 81, No. 1, 2000, pp. 82-87.

[3] Y. L. Xiong and D. R. Kuspski, "Time-Dependent Marinade Absorption and Retention, Cooking Yield, and Pa- 
latability of Chicken Fillets Marinated in Various Phosphate Solutions," Poultry Science, Vol. 78, No. 7, 1999, pp. 1053-1059.

[4] Y. L. Xiong, "Muscle Protein," In: R. Y. Yada, Ed., Proteins in Food Processing, Woodhead Publ. Ltd., London, 2004, pp. 100-122.

http://dx.doi.org/10.1533/9781855738379.1.100

[5] D. P. Smith and L. L. Young, "Marination Pressure and Phosphate Effects on Broiler Breast Fillet Yield, Tenderness, and Color," Poultry Science, Vol. 86, No. 12, 2007, pp. 2666-2670. http://dx.doi.org/10.3382/ps.2007-00144

[6] M. Petracci, L. Laghi, P. Rocculi, S. Rimini, V. Panarese, M. A. Cremonini and C. Cavani, "The Use of Sodium Bicarbonate for Marination of Broiler Breast Meat," Poultry Science, Vol. 91, No. 2, 2012, pp. 526-534. http://dx.doi.org/10.3382/ps.2011-01753

[7] S. Barbut, "Poultry Products-Formulation and Gelation," In: S. Barbut, Ed., Poultry Products Processing. An Industry Guide, CRC Press, New York, 2002, pp. 249-288.

[8] J. G. Sebranek, "Basic Curing Ingredients," In: R. Tarte, Ed., Ingredients in Meat Products, Springer, New York, 2009, pp. 1-24. http://dx.doi.org/10.1007/978-0-387-71327-4 1

[9] M. Petracci, M. Bianchi, S. Mudalal and C. Cavani, "Functional Ingredients for Poultry Meat Products," Trends in Food Science and Technology, Vol. 33, No. 1, 2013, pp. 27-39. http://dx.doi.org/10.1016/j.tifs.2013.06.004

[10] P. R. Shread and A. Tali, "Injection of Salt, Tripolyphosphate and Bicarbonate Marinade Solutions to Improve the Yield and Tenderness of Cooked Pork Loin," Meat Science, Vol. 68, No. 2, 2004, pp. 305-311. http://dx.doi.org/10.1016/j.meatsci.2004.03.012

[11] H. C. Bertram, L. M. Rikke, W. Zhiyun, Z. Xingfei and J. A. Henrik, "Water Distribution and Microstructure in Enhanced Pork," Journal of Agricultural and Food Chemistry, Vol. 56, No. 16, 2008, pp. 7201-7207. http://dx.doi.org/10.1021/jf8007426

[12] D. Barbanti, and M. Pasquini, "Influence of Cooking Conditions on Cooking Loss and Tenderness of Raw and Marinated Chicken Breast Meat," LWT-Food Science and Technology, Vol. 38, No. 8, 2005, pp. 895-901.

[13] B. Mora, E. Curti, E. Vittadini and D. Barnanti, "Effect of Different Air/Steam Convection Cooking Methods on Turkey Breast Meat: Physical Characterization, Water Status and Sensory Properties," Meat Science, Vol. 88, No. 3, 2011, pp. 489-497. http://dx.doi.org/10.1016/j.meatsci.2011.01.033

[14] R. E. Jeacocke, "Continuous Measurement of the $\mathrm{pH}$ of Beef Muscle in Intact Beef Carcasses," Journal of Food Technology, Vol. 12, No. 4, 1977, pp. 375-386. http://dx.doi.org/10.1111/j.1365-2621.1977.tb00120.x

[15] M. Petracci and E. Baéza, "Harmonization of Methodologies for the Assessment of Poultry Meat Quality Features," World's Poultry Science Journal, Vol. 68, No. 1, 2011, pp. 137-153. http://dx.doi.org/10.1017/S0043933911000122

[16] AOAC, "Meat and Meat Products," In: Official Methods of Analysis, 15th Edition, Vol. 2, Assoc. Off. Anal. Chem., Washington DC, pp. 931-948.

[17] R. Van Laack, "The Role of Proteins in Water-Holding Capacity of Meat," In: Y. Xiong, C. Ho and F. Shahidi, Eds., Quality Attributes of Muscle Foods, Springer, New York, 1999, pp. 309-318. http://dx.doi.org/10.1007/978-1-4615-4731-0 21

[18] R. Sams, D. M. Janky and S. A. Woodward, "Comparison of Two Shearing Methods for Objective Tenderness Evaluation and Two Sampling Times for Physical-Characteristic Analyses of Early Harvested Broiler Breast Meat," Poultry Science, Vol. 69, No. 2, 1990, pp. 348353. http://dx.doi.org/10.3382/ps.0690348

[19] N. C. Brake and O. R. Fennema, "Glass Transition Values of Muscle Tissue," Journal of Food Science, Vol. 64, No. 1, 1999, pp. 10-15. http://dx.doi.org/10.1111/j.1365-2621.1999.tb09851.x

[20] Y. Y. Roos, "Melting-Behavior, Denaturation, and FreezeDrying of Reindeer Meat," LWT-Food Science and Technology, Vol. 19, No. 3, 1986, pp. 218-221.

[21] CIE, "Recommendations on Uniform Color Spaces, Color Differences, and Equations. Psychometric Color Terms," CIE Publication 15 (Suppl. 2), Commission Internationale de l'Eclairage, Colorimetry, Paris, 1976.

[22] H. C. Bertam, S. B. Engelsen, H. Busk, A. H. Karlsson and H. J. Andersen, "Water Properties during Cooking of Pork Studied by Low-Field NMR Relaxation: Effects of Curing and the RN-Gene," Meat Science, Vol. 66, No. 2, 2004, pp. 437-446.

http://dx.doi.org/10.1016/S0309-1740(03)00132-3

[23] D. Smith, "Functional Properties of Muscle Proteins in Processed Poultry Products," In: A. R. Sams, Ed., In Poultry Meat Processing, CRC Press, Boca Raton, 2001, pp. 181-194.

[24] G. Offer and P. Knight, "Developments in Meat Science," In: R. Lawrie, Ed., The Structural Basis of Water Holding in Meat, Elsevier Applied Science, New York, 1988, pp. 89-190. http://dx.doi.org/10.1016/j.meatsci.2003.10.010

[25] O. Sorheim, R. Ofstad and P. Lea, "Effects of Carbon Dioxide on Yield, Texture and Microstructure of Cooked Ground Beef," Meat Science, Vol. 67, No. 2, 2004, pp. 231-236.

[26] K. L. Pearce, K. Rosenvold, H. J. Anderson and D. L. Hopkins, "Water Distribution and Mobility in Meat during the Conversion of Muscle to Meat and Aging and the Impacts on Fresh Meat Quality Attributes: A Review," Meat Science, Vol. 89, No. 10, 2011, pp. 111-124.

[27] M. Qiao, D. L. Fletcher, D. P. Smith and J. K. Northcutt, "Effect of Raw Broiler Breast Meat Color Variation on Marination and Cooked Meat Quality," Poultry Science, Vol. 81, No. 2, 2002, pp. 276-280.

[28] L. Young, J. Cason, D. Smith, C. Lyon, J. Dickens and J. Walker, "Effects of Electrical Stimulation and Simulated Conventional and Extended Chilling Method on Cooked Chicken Breast Meat Texture and Yield," International Journal of Poultry Science, Vol. 4, No. 2, 2005, pp. 60-63. http://dx.doi.org/10.3923/ijps.2005.60.63

[29] C. E. Lyon, B. G. Lyon and J. A. Dickens, "Effects of 
Quality of Poultry Meat, Carcass Stimulation, Breast Meat Deboning Time, and Marination on Color and Texture of Broiler," The Journal of Applied Poultry Research, Vol. 7, No. 1, 1998, pp. 53-60.

[30] D. P. Smith and L. L. Young, "Marination Pressure and Phosphate Effects on Broiler Breast Fillet Yield, Tenderness and Color," Poultry Science, Vol. 86, No. 12, 2007, pp. 2666-2670. http://dx.doi.org/10.3382/ps.2007-00144

[31] L. L. Young and C. E. Lyon, "Effect of Post-Chill Aging and Sodium Tripolyphosphates on Moisture Binding Properties, Color, and Warner-Bratzler Shear Values of Chicken Breast Meat," Poultry Science, Vol. 76, No. 11, 1997, pp. 1587-1590.

[32] C. D. Allen, D. L. Fletcher, J. K. Northcutt and S. M. Russell, "The Relationship of Broiler Breast Color to Meat Quality and Shelf-Life," Poultry Science, Vol. 77, No. 2, 1998, pp. 361-366.

[33] L. L. Young and C. E. Lyon, "Effects of Rigor State and Addition of Polyphosphates on the Color of Cooked Turkey Meat," Poultry Science, Vol. 73, No. 7, 1994, pp. 1149-1152. http://dx.doi.org/10.3382/ps.0731149

[34] O. A. Young and J. West, "Meat Color," In: Y. H. Hui, W. K. Nip, R. Rogers and O. Young, Eds., Meat Science and Applications, Marcel Dekker Inc., New York, 2001, pp. 39-69. http://dx.doi.org/10.1201/9780203908082.ch3

[35] C. Z. Alvarado and A. R. Sams, "Injection Marination Strategies for Remediation of Pale, Exudative Broiler Breast Meat," Poultry Science, Vol. 82, No. 8, 2003, pp. 1332-1336.

[36] A. R. Sen, B. M. Naveena, M. Muthukumar, Y. Babji and T. R. K. Murthy, "Effect of Chilling, Polyphosphate, and Bicarbonate on Quality Characteristics of Broiler Breast Meat," British Poultry Science, Vol. 46, No. 4, 2005, pp. 451-456. http://dx.doi.org/10.1080/00071660500191072

[37] J. J. Sindelar, F. Prochaska, J. Britt, G. L. Smith and W.
N. Osburn, "Strategies to Eliminate a Typical Flavors and Aromas in Sow Loins. II Consumer Acceptance of Loins Marinated with Sodium Tripolyphosphate and Sodium Bicarbonate," Meat Science, Vol. 65, No. 4, 2003, pp. 1223-1230. http://dx.doi.org/10.1016/S0309-1740(03)00028-7

[38] S. T. Joo, R. G. Kauffman, B. C. Kim and G. B. Park, "The Relationship of Sarcoplasmic and Myofibrillar Protein Solubility to Colour and Water-Holding Capacity in Porcine Longissimus Muscle," Meat Science, Vol. 52, No. 3, 1999, pp. 291-297. http://dx.doi.org/10.1016/S0309-1740(99)00005-4

[39] R. A. Lawrie, "Lawrie's Meat Science," 6th Edition, Woodhead Publ., Oxford, Cambridge and London, 1998.

[40] A. V. A. Resurrección, "Sensory Aspects of Consumer Choices for Meat and Meat Products," Meat Science, Vol. 66, No. 1, 2003, pp. 11-20. http://dx.doi.org/10.1016/S0309-1740(03)00021-4

[41] H. B. Hedrick, D. E. Albele, J. C. Forrest, M. D. Judge and R. A. Merkel, "Principles of Meat Science," Kendall/Hand Publishing Company, Dubuque, 1993.

[42] G. R. Trout, "Variation in Myoglobin Denaturation and Color of Cooked Beef, Pork and Turkey Meat as Influenced by $\mathrm{pH}$, Sodium Chloride, Sodium Tripolyphosphate and Cooking Temperature," Journal of Food Science, Vol. 54, No. 3, 1989, pp. 536-544. http://dx.doi.org/10.1111/j.1365-2621.1989.tb04644.x

[43] R. E. Rust, "Science of Meat and Meat Products," In: J. F. Schweigert and B. S. Schweigert, Eds., Food and Nutrition, Press Inc., Trumbull, 1987, pp. 457-485.

[44] P. R. Sheard and A. Tali, "Injection of Salt, Tripolyphosphate and Bicarbonate Marinade Solutions to Improve the Yield and Tenderness of Cooked Pork Loin," Meat Science, Vol. 68, No. 2, 2004, pp. 305-311. http://dx.doi.org/10.1016/j.meatsci.2004.03.012 